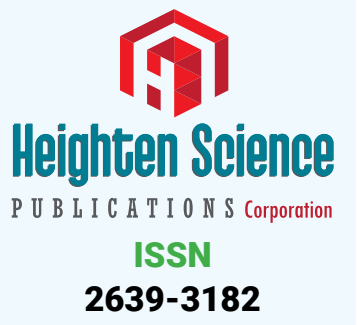

*Address for Correspondence: Mohammad Reza Javan, Department of Biochemistry and Immunology, Faculty of Medicine, Zabol University of Medical Sciences, Zabol, Iran, Email: m.r.javan@zbmu.ac.ir

Submitted: 21 October 2017

Approved: 28 October 2017

Published: 30 October 2017

Copyright: @ 2017 Javan MR, et al. This is an open access article distributed under the Creative Commons Attribution License, which permits unrestricted use, distribution, and reproduction in any medium, provided the original work is properly cited

Keywords: EAE; MS; Gene expression; Cytokine; Sesamum indicum seeds oil
Research Article

\section{Cytokine Modulatory Effects of Sesamum Indicum Seeds Oil Ameliorate Mice with Experimental Autoimmune Encephalomyelitis}

\author{
Mohammad Reza Javan*, Mohammad Reza Zamani², Saeed \\ Aslani ${ }^{2}$, Ghader Dargahi Abbasabad ${ }^{3}$, Masoud Beirami Khalaj ${ }^{4}$ and \\ Hamed Serati-Nouri ${ }^{5}$ \\ 'Department of Biochemistry and Immunology, Faculty of Medicine, Zabol University of Medical \\ Sciences, Zabol, Iran \\ ${ }^{2}$ Department of Immunology and Biology, School of Medicine, Tehran University of Medical \\ Sciences, Tehran, Iran \\ ${ }^{3}$ Razi Hospital, Tabriz University of Medical Sciences, Tabriz, Iran \\ ${ }^{4}$ Department of Animal Science, Faculty of Agriculture, University of Tabriz, Tabriz, Iran \\ ${ }^{5}$ Stem Cell Research Center, Tabriz University of Medical Sciences, Tabriz, Iran
}

\section{Abstract}

Background: Multiple sclerosis (MS) is an autoimmune disorder of the central nerve system (CNS), which affects the brain and spinal cord. Experimental autoimmune encephalomyelitis (EAE) is the most commonly applied experimental model for studying the MS. The aim of this study was to determine the effects of Sesamum indicum seeds oil on Experimental Autoimmune Encephalomyelitis (EAE) in mice.

Methods: Sesame oil was administrated intraperitoneally three days before immunization. IFN- $\gamma$, IL-10, IL-17 and TGF- $\beta$ levels and mRNA expression in supernatant of and within cultured mononuclear cells were assessed.

Results: According to our results, sesame oil treated mice demonstrated significant disease severity reduction ( $P=0.01$ and 0.001 , respectively). Treated EAE mice also represented statistically significant delay in the onset of symptoms in comparison with control group. The average IFN-y levels and mRNA of sesame oil treated EAE mice were less than untreated EAE group. IL-10 and TGF- $\beta$ levels and mRNA did not differ significantly in sesame oil treated EAE mice in comparison to untreated EAE group. IL-17 levels and mRNA were also found to be decreased significantly in treated mice in comparison to untreated mice.

Conclusions: Even thoughTH1 and TH17 cells through secretion of IFN- $\gamma$ and IL-17, respectively, are involved in the pathogenesis of multiple sclerosis and EAE, but IL-10 has been shown to exhibit suppressive effects on these disorders. It can be concluded that sesame oil is able to induce TH2 and TH17-related immune responses and suppress $\mathrm{TH} 1$ type in $\mathrm{EAE}$.

\title{
Introduction
}

Experimental autoimmune encephalomyelitis (EAE) is an induced disorder that damages the central nervous system (CNS) and is considered as a model for human multiple sclerosis (MS) [1]. In this disorders, the nervous system is affected and cell mediated immune responses (CD4+ T cell) have a crucial role in the pathogenesis of the disease leading to inflammation and/or demyelination of the CNS [2]. CD4+ $\mathrm{T}$ cells, which are responsible in cell mediated immune responses, are divided into two major subgroups; T helper 1 and T helper 2 (TH1 \& TH2). TH1 cells augment the cell immunity by producing gamma interferon (IFN- $\gamma$ ) as well as interleukin 12 (IL12). However, TH2 cells produce IL-4, IL-5 and IL- 10 and consequently increase the activity of humoral immunity. These two subgroups, in normal physiological status, show regulatory effects on each other [3]. Transforming growth factor $\beta$ (TGF- $\beta$ ) is 
an immunoregulator mediator produced mainly through TH3 or Treg (regulatory T) cells [4] whose inhibitory effects on immune responses have been demonstrated [5]. Faria AMC et al., indicated that increased TGF- $\beta$ levels is related with EAE suppression [6]. TGF- $\beta$ levels are also increased in MS patients as a negative feedback of immune system to ameliorate disease severity and complications [7]. Interleukin 17 (IL-17) is a proinflammatory cytokine which is outstandingly produced by TH17 cells. Moreover, through IL-17 production and secretion, activated T cells and a variety of cell types has also been reported to be contributing factor in some autoimmune diseases including EAE [8]. The oil of the Sesamum indicum (sesame) seeds has long been considered a very demanding health food in Iran and other Asian countries. Reports show that sesame oil can act as an antioxidant agent, reduce lipid peroxidation, exhibit healing effects on damaged tissue and provide anti-inflammatory function [9]. Other studies, however, disclose that sesame oil could cause allergic reactions [10]. Given the fact that TH2 cells participate in allergic reactions by producing IL-4, it could be hypothesized that sesame oil can augment the TH2 responses and consequently suppress the TH1 responses. Accordingly we established our study based upon this hypothesis and investigated the effects of sesame oil over TH1 (IFN- $\gamma$ ) and TH2 (IL-10) TH17 (IL-17) and Treg (TGF- $\beta$ ) in EAE mice. In another experiment parallel to this study, we also evaluated the effects of Olive oil as an anti-inflammatory agent to gain unique and specific results.

\section{Materials and Methods}

\section{Mice}

Forty female C57BL/6 mice (with 1.5-2 months old and 22 \pm 1 g weight) were purchased from Pasteur Institute of Iran (Tehran, Iran). The room was on a 12-12 hour's light-dark cycle, and the temperature was maintained between 21 and $23^{\circ} \mathrm{C}$. All steps of research protocol were approved by ethics committee of Tehran University of Medical Sciences and University of Tabriz.

\section{EAE induction}

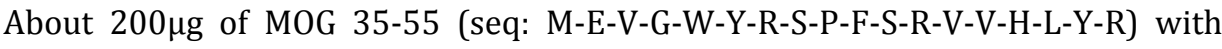
purity $>95 \%$ was emulsified in complete Freund's adjuvant containing $1 \mathrm{mg} / \mathrm{ml}$ of heat-killed Mycobacterium tuberculosis H37RA (Sigma-Aldrich, USA) and was administrated intraperitoneally on day 0. Additionally, mice received $200 \mathrm{ng}$ of pertussis toxin intraperitoneally in $0.5 \mathrm{ml}$ of PBS on days 0 and 2 . For the control group, all of the procedures above except than MOG administration, were carried out.

\section{Clinical course of EAE}

Clinical symptoms of EAE in mice were assessed daily with a 0 to 6 point scoring system: 0 , normal; 1 , flaccid tail; 2 , impaired righting reflex and/or gait; 3 , partial hindlimb paralysis; 4, total hind-limb paralysis; 5 , hind-limb paralysis with partial forelimb paralysis; 6 , moribund state [11]. To investigate the effects of sesame oil on EAE progression, three days before disease induction, 30 mice divided into two age and weight matched groups. Daily administration of sesame oil continued until day 20 .

\section{Sesame oil treatment}

For patient group: Each day sesame oil ( $4 \mathrm{ml} / \mathrm{kg} /$ day) injected intraperitoneally to each 15 case EAE mice [12]. For disease control group: $4 \mathrm{ml}$ phosphate buffer intraperitoneally administrated to each control EAE mice daily. Ten C57BL/6 mice matched with case and control groups by sex, age and weight considered as healthy control group and received phosphate buffered saline in the same manner.

\section{Isolation and culture of splenic mononuclear cells}

Following cervical dislocation, the spleen was removed and placed in $60 \times 15$ mm petri dish containing $4 \mathrm{ml}$ complete RPMI-5 and 5\% FBS and then pieced into completely small fragments. About $3 \mathrm{ml}$ of cell suspension carefully transferred to same 
amount of Ficoll gradient and centrifuged for 15 minutes $\left(600 \mathrm{~g}\right.$ and $\left.4^{\circ} \mathrm{C}\right)$. Afterwards, mononuclear cells were collected by Pasteur pipette and washed twice by phosphate buffered saline and then centrifuged. The precipitated cells were mixed in complete medium containing $10 \% \mathrm{FCS}$, as suspension of $2 \times 10^{6}$ cells $/ \mathrm{ml}$. Cells were cultured in the presence and absence of MOG 35-55 (50 $\mu \mathrm{g} / \mathrm{ml})$ in 48-well cell culture plates for 96 hours in an incubator containing $5 \% \mathrm{CO}_{2}$.

\section{Measurement of IFN- $\gamma$, IL-10, IL-17 and TGF- $\beta$ levels in the supernatant}

After 96 hours, the supernatant of cultured mononuclear cells in presence and absence of antigen were collected in order to assess the cytokine levels (Qiagen, Germany). Different dilutions of standard solutions were prepared in dilution buffer and separately added to each $100 \mu \mathrm{l}$ well. Supernatants were also added to the wells, then specific anti IFN- $\gamma$, IL-10, IL-17 and TGF- $\beta$ conjugates with $1 / 1000$ dilution were added to the plate following 2 hours incubation at $37^{\circ} \mathrm{C}$, and finally washing process was carried out. After 2 hours incubation at $37^{\circ} \mathrm{C}$ and then washing, the enzyme substrate in $100 \mu \mathrm{l}$ volume was added to each well. After adding the stop solution, the Optical Density (OD) was deliberated by the light absorption in 450nm through ELISA Reader. Finally, cytokine levels were determined after drawing the ELISA standard curve based upon the ODs.

\section{RNA extraction, complementary DNA synthesis and real-time quantitative PCR}

The total cellular RNA was extracted from cultured mononuclear cells using the High Pure RNA Isolation Kit (Roche, Germany). After that, complementary DNA (cDNA) was synthesized from the RNA of the cells using the Transcriptor First Strand cDNA Synthesis Kit (Roche, Germany). Afterwards, quantitative analysis was carried out using the StepOne Plus Real-Time PCR System (Applied Biosystems, Foster City, CA, USA). A widely used method to represent relative gene expression, the comparative $C_{T}$ method, was used to evaluate expression as previously described by Schmittgen and Livak [13].

\section{Statistical Analysis}

Data analysis was done using SPSS software version 21 (SPSS, Chicago, IL, USA). Through the Mann-Whitney nonparametric test, group comparisons of continues variables were carried out. The GraphPad Prism version 5.00 for Windows (GraphPad Software, La Jolla California USA, www.graphpad.com) was applied to illustrate data through graph. All results are expressed as mean \pm standard deviation (SD) with statistical significance set at $5 \%$.

\section{Results}

\section{Symptoms}

Our results showed that weight loss in EAE mice which received sesame oil was significantly low $(P=0.01)$ in comparison to control group (Figure $1 \mathrm{~A})$. First symptoms of EAE in treated mice, occurred 9 days after disease induction. But these symptoms in untreated mice initiated 6 days after induction (Figure 1B). The maximum severity of symptoms (The day in which the average severity of symptoms in a group is greater than the other group) in treated group in comparison to untreated group was retarded; day 23 and 15 respectively. Also the average of symptoms among the members of treated group was less than untreated group at the maximum sever day; $6.5 \pm 0.5$ and $5.2 \pm 0.7$, respectively (Figure $1 ; P=0.001$ ).

\section{IFN-Y:}

We observed that splenic mononuclear cells in the presence of MOG 35-55 from sesame oil treated EAE mice expressed IFN- $\gamma$ mRNA less than untreated EAE group 

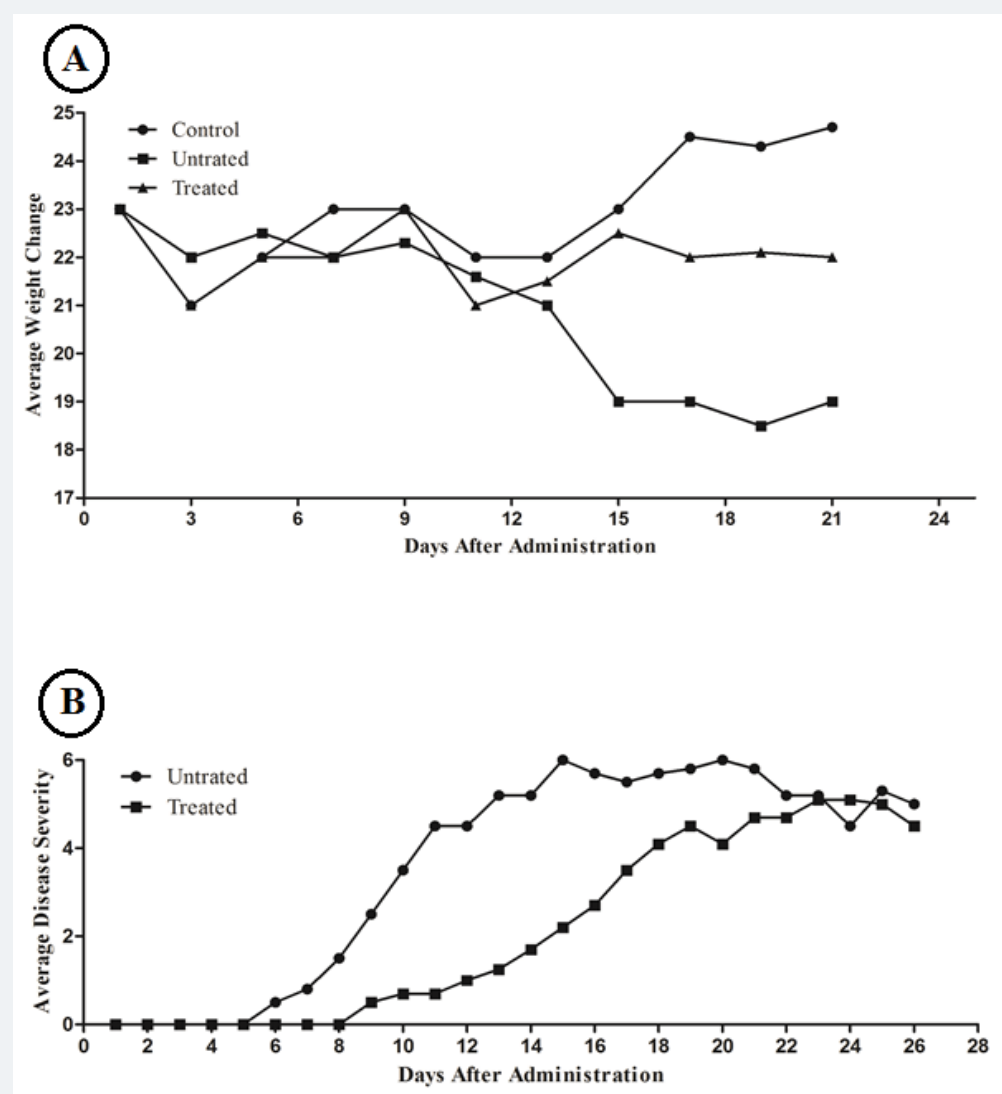

Figure 1: (A) Average weight changes comparison among treated, untreated and control groups. (B) Daily average disease severity between treated and untreated groups.

(0.41 times downregulated, $P=0.02$; Figure 2 IA). We also found that the average IFN- $\gamma$ levels in supernatant of splenic mononuclear cells in the presence of MOG 35-55 from sesame oil treated EAE mice were less than untreated EAE group $(519 \pm 31 \mathrm{pg} / \mathrm{ml} v \mathrm{v}$. $788 \pm 45 \mathrm{pg} / \mathrm{ml}, P=0.0003$; Figure 2 IB). On the other side, splenic mononuclear cells in the absence of MOG 35-55 from sesame oil treated EAE mice expressed IFN- $\gamma$ mRNA insignificantly less than untreated EAE group (Fold Change $=-0.73, P=0.67$; Figure 2 IC). Also, the average IFN- $\gamma$ levels in supernatant of splenic mononuclear cells in the absence of MOG 35-55 from sesame oil treated EAE mice were insignificantly less than

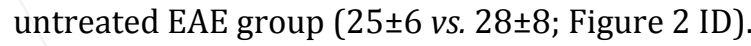

IL-17

Splenic mononuclear cells in the presence of MOG 35-55 from sesame oil treated EAE mice expressed the IL-17 mRNA lower than untreated group (0.35 times downregulated, $P=0.01$; Figure 2 IIA) As such, IL-17 levels in supernatant of splenic mononuclear cells in the presence of MOG 35-55 from sesame oil treated EAE mice were lower than untreated group $(109 \pm 13 \mathrm{pg} / \mathrm{ml} v s .182 \pm 11 \mathrm{pg} / \mathrm{ml} ; P=0.001$; Figure 2 IIB). However, splenic mononuclear cells in the absence of MOG 35-55 from sesame oil treated EAE mice expressed IL-17 mRNA insignificantly less than untreated EAE group (Fold Change=-0.95, $P=0.89$; Figure 2 IIC). Also, average IL-17 levels in supernatant of splenic mononuclear cells in the absence of MOG 35-55 from sesame oil treated EAE mice were insignificantly less than untreated EAE group (31 \pm 4 vs. 34 \pm 7 ; Figure 2 IID). IL-10

Although the IL-10 levels and mRNA expression in supernatant of and within splenic mononuclear cells in the absence of MOG 35-55 from sesame oil treated EAE mice were different than untreated group, these differences were statistically insignificant (Table s 1,2, Figure 2 III). 
(I)
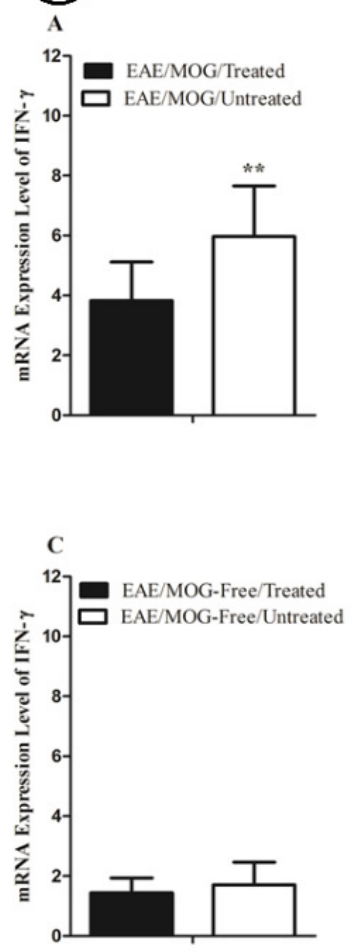

(III)
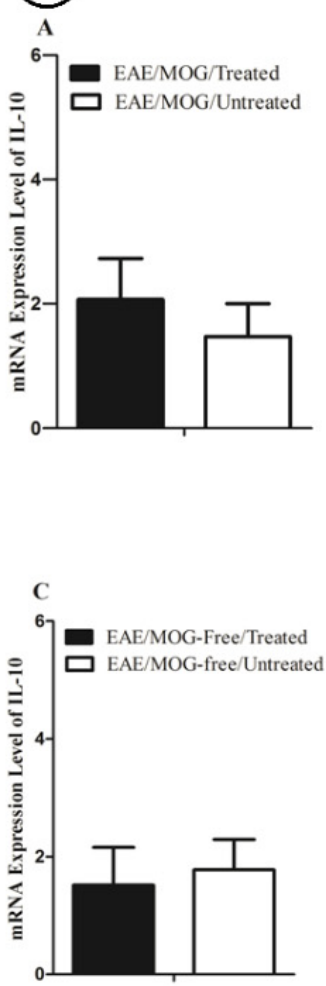
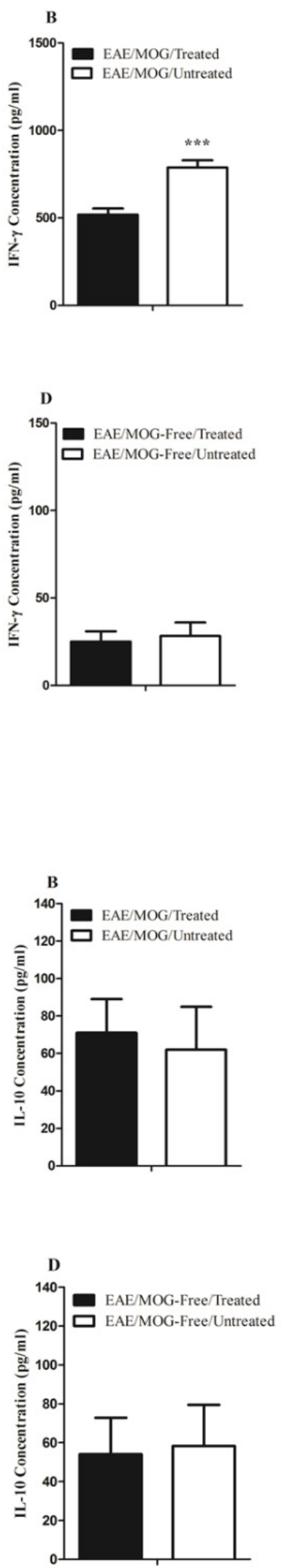

(II)
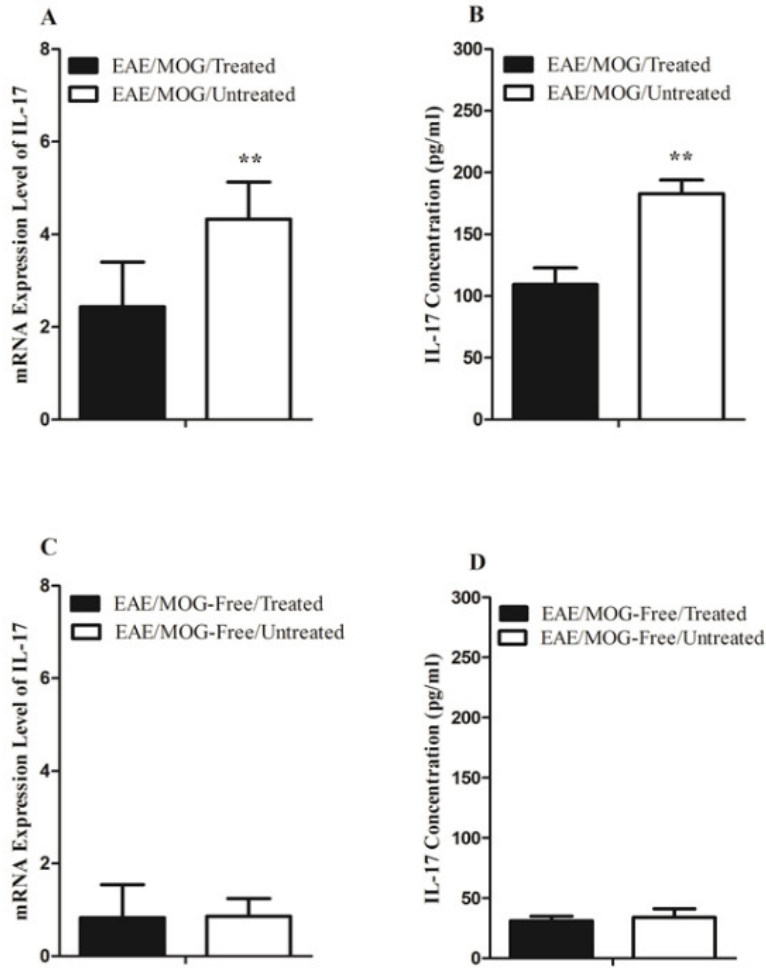

\section{(IV)}
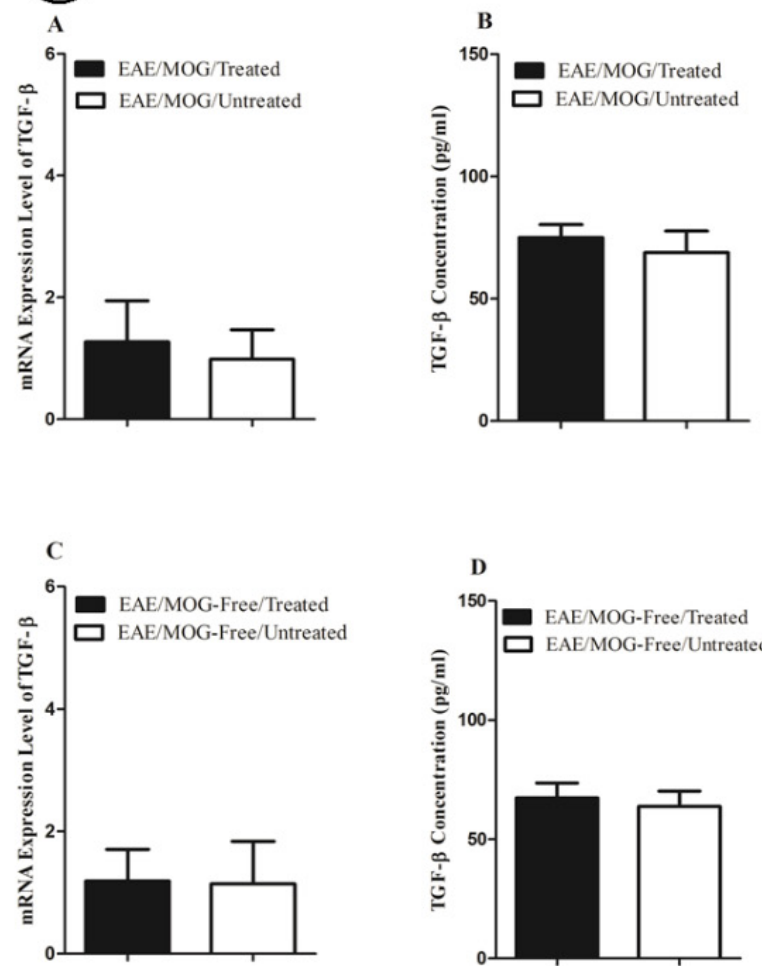

Figure 2: Bar graphs illustrate concentration and relative mRNA expression of the IFN-y (I), IL-17 (II), IL-10 (III), and TGF- $\beta$ (IV) in the supernatant of and within mononuclear cells from four categories of mice. 


\section{TGF- $\beta$}

Similarly, we could find no significant changes in TGF- $\beta$ levels and mRNA expression between treated and untreated mice (Tables 1,2, Figure 2 IV). The effects of Olive oil on the same parameters were carried out parallel to this study, but we could find no significant change (Table 3 ).

\section{Discussion}

Sesame oil was observed to reduce the IFN- $\gamma$ levels and the disease severity in EAE mice. IFN- $\gamma$ is an important cytokine of cell mediated immunity (CMI) which mainly produced by macrophages and T cells. The IFN- $\gamma$ produced by TH1 cells plays a meaningful role in the pathogenesis of MS and EAE $[14,15]$. Sepulcre et al., indicated that there is a relation between the number of IFN- $\gamma$ producing cells and the severity of disease in MS patients [16]. Investigations also indicate that anti-IFN- $\gamma$ has curative impression on the TH1 mediated autoimmune disorders. Furthermore, studies report that there is an enhanced IFN- $\gamma$ levels during MS and EAE [17]. It has been shown that IFN- $\gamma$ increases the disease severity through leukocyte infiltration in brain, activation of macrophages and nitric oxide production [18]. There is no clear evidence regarding a mechanism by which the sesame oil can reduce IFN- $\gamma$ and disease severity. Some studies show that sesame oil has the potential of apoptosis induction in tumor cells [19]. Miyahara et al., showed that sesame oil has apoptotic effects on Molt-4B lymphoid cell line [20] and Salem et al., demonstrated that administration of sesame oil is capable of suppressing the proliferation and metastasis in EL4 lymphoma cell line in C57BL/6 mice [21]. Considering these proofs, it can be prematurely inferred that sesame oil may act through inducing apoptosis or restriction of inflammatory cells proliferation and/ or modulating TH1 and TH2 responses leading to reduce IFN- $\gamma$ levels and therefor diminish EAE severity.

On the other side, IL-17 levels were realized to be decreased in treated mice in comparison to untreated group. Observations suggest that IL-17 plays an pivotal role

\begin{tabular}{|c|c|c|c|c|}
\hline Cytokines & IL-10 & IFN-Y & TGF- $\beta$ & IL-17 \\
\hline \multicolumn{5}{|c|}{$\begin{array}{l}\text { Groups presence of / absence of presence of / absence of presence of / absence of presence of / absence of MOG } \\
\text { MOG MOG MOG MOG MOG MOG MOG }\end{array}$} \\
\hline $\begin{array}{l}\text { Sesame oil treated } \\
\text { EAE Mice }\end{array}$ & $71 \pm 18 / 54 \pm 14$ & $519 \pm 31 / 25 \pm 6$ & $75 \pm 5 / 67 \pm 6$ & $109 \pm 13 / 31 \pm 4$ \\
\hline Untreated EAE Mice & $62 \pm 23 / 58 \pm 22$ & $788 \pm 45 / 28 \pm 8$ & $71 \pm 8 / 63 \pm 7$ & $182 \pm 11 / 34 \pm 7$ \\
\hline$P$ value & N.S/N.S & $0.0003 /$ N.S & N.S/N.S & $0.001 /$ N.S \\
\hline
\end{tabular}
N.S: None Significant.

Table 2: Fold Change of mRNA expression of IL-10, IFN- - , TGF- $\beta$ and IL-17 in sesame oil treated and untreated EAE mice.

\begin{tabular}{|c|c|c|c|c|}
\hline Compared Groups & $\begin{array}{l}\text { IL-10 } \\
\text { F.C (P) }\end{array}$ & $\begin{array}{l}\text { IFN-Y } \\
\text { F.C (P) }\end{array}$ & $\begin{array}{l}\text { TGF- } \beta \\
\text { F.C (P) }\end{array}$ & $\begin{array}{l}\text { IL-17 } \\
\text { F.C (P) }\end{array}$ \\
\hline $\begin{array}{c}\text { MOG/Treated vs. MOG/ } \\
\text { Untreated }\end{array}$ & $+1.02(P=0.77)$ & $-0.41(P=0.02)$ & $+1.07(P=0.27)$ & $-0.35(P=0.01)$ \\
\hline $\begin{array}{l}\text { MOG-Free/Treated vs. MOG- } \\
\text { Free/Untreated }\end{array}$ & $-0.87((P=0.58)$ & $-0.73(P=0.67)$ & $+1.01(P=0.48)$ & $-0.95(P=0.89)$ \\
\hline
\end{tabular}

Table 3: Average IL-10, IFN- $\gamma$, TGF- $\beta$ and IL-17 levels in Olive oil treated and untreated EAE mice.

\begin{tabular}{|c|c|c|c|c|}
\multicolumn{1}{|c|}{$\begin{array}{c}\text { IL-10 } \\
\text { Groups presence of / absence of presence of / absence of presence of / absence of presence of / absence of MOG } \\
\text { MOG MOG MOG MOG MOG MOG MOG }\end{array}$} \\
\hline $\begin{array}{r}\text { Olive oil treated EAE } \\
\text { Mice }\end{array}$ & $69 \pm 2 / 7 \pm 6$ & $720 \pm 5 / 33 \pm 5$ & $70 \pm 2 / 65 \pm 2$ & $95 \pm 2 / 33 \pm 7$ \\
\hline $\begin{array}{c}\text { Untreated EAE Mice } \\
P \text { value }\end{array}$ & $70 \pm 1 / 55 \pm 9$ & $730 \pm 8 / 30 \pm 2$ & $74 \pm 1 / 63 \pm 7$ & $101 \pm 9 / 37 \pm 2$ \\
\hline
\end{tabular}


in the activation of encephalitogenic T cells during the sensitization phase of EAE [22]. On the contrary, it has been recently reported that IL-17 producing CD4+ T cells enhance the disease severity of EAE and that treatment with anti-IL-17 neutralizing antibodies during the elicitation phase suppressed disease development [23]. These observations vigorously point out that IL-17 is involved in the pathogenesis of EAE during both the sensitization and elicitation phases. It can be inferred that IL-17 negatively manipulates the development of IFN- $\gamma$ producing TH1 cells. As a result, IL17 and IFN $-\gamma$ may mutually collaborate to regulate the development of these cytokine producer cells over the course of immune responses.

Our findings show that IL-10 levels are increased, however insignificantly, in sesame oil treated EAE mice in comparison to untreated group. IL-10 is an immunomodulatory cytokine produced by TH2 cells [2] and has suppressive effect on TH1 responses [24]. Oneill et al., described the IL-10 function in regarding to suppressive effect on EAE progression [25]. IL-10 is thought to act probably through modulation of TH1 responses and reducing the IFN- $\gamma$ production which leads to disease amelioration. It has been shown that sesame oil has allergic properties [10]. Since TH2 responses are essential in most perspectives of allergic manifestations, hence sesame oil may detour the immune responses toward TH2. Further surveys would be advantageous to shed new light on the way that sesame oil modifies immune responses.

TGF- $\beta$ is involved in the induction of oral tolerance in EAE [26]. TGF- $\beta$ itself has been indicated, when administered systemically, suppresses autoimmunity, both in rat and mouse disease models, including EAE [27]. The relation between sesame oil and TGF- $\beta$ levels as a Treg product also studied in order to find a plausible effect on EAE suppression, but in the present experiment we could find no significant result.

To sum up all the facts, it seems that implication of sesame oil in modulating the immune response, procrastinate the onset of EAE symptoms as well suppress EAE severity, may root in reduction of IFN- $\gamma$ and IL17 and also incremen ent of IL-10 production.

\section{References}

1. Ransohoff RM. Animal models of multiple sclerosis: the good, the bad and the bottom line. Nat Neurosci. 2012; 15: 1074-1077. Ref.: https://goo.gl/MVZUjC

2. Rengarajan J, Szabo SJ, Glimcher LH. Transcriptional regulation of Th1/Th2 polarization. Immunol Today. 2000; 21: 479-483. Ref.: https://goo.gl/oTL9LX

3. de Andrés C, Rodríguez-Sáinz MC, Muñoz-Fernández MA, López-Lazareno N, Rodríguez-Mahou M, et al. Short-term sequential analysis of sex hormones and helper T cells type 1 (Th1) and helper T cells type 2 (Th2) cytokines during and after multiple sclerosis relapse. Eur Cytokine Netw. 2004; 15 : 197-202. Ref.: https://goo.gl/LDHzZf

4. Sakaguchi S. Editor Regulatory T cells. Springer seminars in immunopathology. 2006.

5. Li MO, Wan YY, Sanjabi S, Robertson AK, Flavell RA. Transforming growth factor- $\beta$ regulation of immune responses. Annu Rev Immunol. 2006; 24: 99-146. Ref.: https://goo.gl/xg5nWv

6. Faria AMC, Maron R, Ficker SM, Slavin AJ, Spahn T, et al. Oral tolerance induced by continuous feeding: enhanced up-regulation of transforming growth factor- $\beta$ /interleukin-10 and suppression of experimental autoimmune encephalomyelitis. J Autoimmun. 2003; 20: 135-145. Ref.: https://goo.gl/iq1wNw

7. John GR, Shankar SL, Shafit-Zagardo B, Massimi A, Lee SC, et al. Multiple sclerosis: re-expression of a developmental pathway that restricts oligodendrocyte maturation. Nat Med. 2002; 8: 1115-1121. Ref.: https://goo.gl/DT6Gvj

8. Ye P, Rodriguez FH, Kanaly S, Stocking KL, Schurr J, et al. Requirement of interleukin 17 receptor signaling for lung CXC chemokine and granulocyte colony-stimulating factor expression, neutrophil recruitment, and host defense. J Exp Med. 2001; 194: 519-528. Ref.: https://goo.gl/NL8yFo

9. Hsu DZ, Su SB, Chien SP, Chiang PJ, Li YH, et al. Effect of sesame oil on oxidative-stress-associated renal injury in endotoxemic rats: involvement of nitric oxide and proinflammatory cytokines. Shock. 2005; 24: 276-280. Ref.: https://goo.gl/4wurMJ 
10. Gangur V, Kelly C, Navuluri L. Sesame allergy: a growing food allergy of global proportions? Ann Allergy Asthma Immunol. 2005; 95: 4-11. Ref.: https://goo.gl/iCDzuC

11. Fillatreau S, Sweenie $\mathrm{CH}, \mathrm{McGeachy} M J$, Gray $\mathrm{D}$, Anderton $\mathrm{SM}$. B cells regulate autoimmunity by provision of IL-10. Nat Immun. 2002; 3: 944-950. Ref.: https://goo.gl/nPkMsk

12. Hsu DZ, Liu MY. Sesame oil protects against lipopolysaccharide-stimulated oxidative stress in rats. Crit Care Med. 2004; 32: 227-231. Ref.: https://goo.gl/SJvknG

13. Schmittgen TD, Livak KJ. Analyzing real-time PCR data by the comparative CT method. Nat Protoc. 2008; 3: 1101-1108. Ref.: https://goo.gl/qKczfW

14. Lassmann $\mathrm{H}$, van Horssen J, Mahad D. Progressive multiple sclerosis: pathology and pathogenesis. Nat Rev Neurol. 2012; 8: 647-656. Ref.: https://goo.gl/978jrj

15. Jiang HR, Milovanović M, Allan D, Niedbala W, Besnard AG, et al. IL-33 attenuates EAE by suppressing IL-17 and IFN- $\gamma$ production and inducing alternatively activated macrophages. Eur J Immunol. 2012; 42: 1804-1814. Ref.: https://goo.gl/agPZNY

16. Tyler A, Mendoza J, Ortega S, Firan M, Karandikar N. CD8+ T-cells are required for the action of glatiramer acetate therapy for autoimmune demyelinating disease. J Immunol. 2011; 186: 164.119. Ref.: https://goo.gl/e6og8R

17. Guinness NM, Dungan LS, Lynch MA, Mills KH. Interferon-gamma-producing natural killer cells are pathogenic in experimental autoimmune encephalomyelitis by promoting $\mathrm{M} 1$ macrophage activation and VLA-4 expression on CD4+ T cells. J Neuroimmunol. 2014; 275: 119-120. Ref.: https://goo.gl/fud1vC

18. Lin W, Lin Y. Interferon-gamma inhibits central nervous system myelination through both STAT1dependent and STAT1-independent pathways. J Neurosci Res. 2010; 88: 2569-2577. Ref.: https://goo.gl/jRvzdr

19. Jacklin A, Ratledge C, Welham K, Bilko D, Newton CJ. The sesame seed oil constituent, sesamol, induces growth arrest and apoptosis of cancer and cardiovascular cells. Ann N Y Acad Sci. 2003; 1010: 374-380. Ref.: https://goo.gl/cieHrT

20. Miyahara $Y$, Hibasami H, Katsuzaki H, Imai K, Komiya T. Sesamolin from sesame seed inhibits proliferation by inducing apoptosis in human lymphoid leukemia Molt 4B cells. Int J Mol Med. 2001; 7: 369-371. Ref.: https://goo.gl/dR2atC

21. Salem ML. Systemic treatment with $n-6$ polyunsaturated fatty acids attenuates EL4 thymoma growth and metastasis through enhancing specific and non-specific anti-tumor cytolytic activities and production of TH1 cytokines. Int Immunopharmacol. 2005; 5: 947-960. Ref.: https://goo.gl/M5H3vN

22. Komiyama Y, Nakae S, Matsuki T, Nambu A, Ishigame $H$, et al. IL-17 plays an important role in the development of experimental autoimmune encephalomyelitis. J Immunol. 2006; 177: 566-573. Ref.: https://goo.gl/1sx7ME

23. Langrish CL, Chen Y, Blumenschein WM, Mattson J, Basham B, et al. IL-23 drives a pathogenic T cell population that induces autoimmune inflammation. J Exp Med. 2005; 201: 233-240. Ref.: https://goo.gl/ga4c2X

24. Skapenko A, Niedobitek GU, Kalden JR, Lipsky PE, Schulze-Koops H. Generation and regulation of human Th1-biased immune responses in vivo: a critical role for IL-4 and IL-10. J Immunol. 2004; 172: 6427-6434. Ref.: https://goo.gl/2dYa8T

25. O'Neill EJ, Day MJ, Wraith DC. IL-10 is essential for disease protection following intranasal peptide administration in the C57BL/6 model of EAE. J Neuroimmunol. 2006; 178: 1-8. Ref.: https://goo.gl/C79y9f

26. Santos L, Al-Sabbagh A, Londono A, Weiner HL. Oral tolerance to myelin basic protein induces regulatory TGF- $\beta$-secreting T cells in Peyer's patches of SJL mice. Cell Immunol. 1994; 157: 439447. Ref.: https://goo.gl/MhkYHF

27. Johns L, Flanders K, Ranges G, Sriram S. Successful treatment of experimental allergic encephalomyelitis with transforming growth factor-beta 1. J Immunol. 1991; 147: 1792-1796. Ref.: https://goo.gl/DwZTmo t of IL-10 production. 